\title{
Transfusions in patients with iron deficiency anemia following release of Choosing Wisely Guidelines
}

\author{
A. Zohaib Siddiqi ${ }^{1} \cdot$ Daniel Grigat $^{3} \cdot$ Shabnam Vatanpour $^{2} \cdot$ Andrew McRae $^{2,3} \cdot$ Eddy S. Lang $^{2,3}$
}

Received: 10 June 2020 / Accepted: 23 December 2020 / Published online: 15 March 2021

(c) The Author(s), under exclusive licence to Canadian Association of Emergency Physicians (CAEP)/ Association Canadienne de Médecine d'Urgence (ACMU) 2021

\begin{abstract}
Background In 2016, based on recommendations of the American Association of Blood Banks (AABB), Choosing Wisely Canada released transfusion guidelines for patients with Iron Deficiency Anemia. The goal of the present study was to examine the number of transfusions given in Calgary emergency departments (EDs) before and after the release of these guidelines. Methods We analyzed 11,786 anemia encounters from January 2014 to December 2019. A transfusion was considered potentially avoidable if the patient's hemoglobin was $>70 \mathrm{~g} / \mathrm{L}$ and if the patient was hemodynamically stable. We used time-series analyses to examine change in rate of total and potentially avoidable transfusions quarterly over the total and pre and post intervention periods.

Results In total, $1409 / 11,786(12.0 \%)$ of the encounters received transfusions; $80.0 \%(1127 / 1409)$ were indicated while $19.9 \%$ (281/1409) were potentially avoidable. In the pre-intervention period, the rate of potentially avoidable transfusions was $21.5 \%$ (133/618) and in the post-intervention period, the rate of potentially avoidable transfusions was $18.7 \%$ (148/791). The rate of potentially avoidable transfusions decreased quarterly at a rate of $0.3 \%$ which did not reach statistical significance $(p=0.06)$. Discussion Our data suggest that the number of potentially avoidable transfusions has not decreased since the release of Choosing Wisely Canada guidelines and local educational initiatives. This may be due to the fact that there is a pre-existing down trend in the number of transfusions provided.
\end{abstract}

Keywords Knowledge translation · Clinical practice guidelines · Quality improvement

\section{Résumé}

Contexte En 2016, sur la base des recommandations de l'AABB (Association américaine des banques de sang) Choisir avec soin Canada a publié des directives sur la pratique transfusionnelle pour les patients atteints d'anémie ferriprive. Le but de la présente étude était d'examiner le nombre de transfusions administrées dans les services d'urgence (SU) de Calgary avant et après la publication de ces directives.

Méthodes Nous avons analysé 11786 cas d'anémie entre janvier 2014 et décembre 2019. Une transfusion était jugée comme potentiellement évitable si l'hémoglobine du patient était $>70 \mathrm{~g} / \mathrm{L}$ et si le patient était stable sur le plan hémodynamique. Nous avons utilisé des analyses de séries chronologiques pour examiner trimestriellement le changement du taux de transfusions totales et potentiellement évitables au cours de l'ensemble des périodes, y compris avant et après l'intervention.

Eddy S. Lang

Eddy.Lang@albertahealthservices.ca

1 Faculty of Medicine and Dentistry, University of Alberta, Edmonton, Canada

2 University of Calgary, Cumming School of Medicine, Calgary, Canada

3 Emergency Department, Alberta Health Services, C321, Foothills Medical Centre, 140329 Street NE, Calgary, AB T2N 2T9, Canada 
Résultats Au total, 1409/11786 (12.0\%) des cas ont reçu des transfusions ; 80.0\% (1127/1409) ont été indiqués tandis que $19.9 \%$ (281/1409) étaient potentiellement évitables. Pendant la période précédant l'intervention, le taux de transfusions potentiellement évitables était de $21.5 \%$ (133/618) et dans la période postérieur à l'intervention, le taux de transfusions potentiellement évitables était de 18,7\% (148/791). Le taux de transfusions potentiellement évitables a diminué chaque trimestre à un taux de $0,3 \%$ qui n'a pas atteint la signification statistique $(p=0,06)$.

Discussion Nos données suggèrent que le nombre de transfusions potentiellement évitables n'a pas diminué depuis la publication des directives de Choisir avec soin Canada et des initiatives éducatives locales. Cela peut être dû au fait qu'il existe une tendance à la baisse préexistante du nombre de transfusions fournies.

\section{Clinician's capsule}

\section{What is known about the topic?}

There is variation in transfusion practices for iron deficiency anemia even though Choosing Wisely has released guidelines.

\section{What did this study ask?}

What was the proportion of avoidable transfusions in Calgary emergency departments from 2014 to 2019 and did educational interventions post-2016 have any effect?

\section{What did this study find?}

There was no significant decrease in potentially avoidable transfusions after educational interventions were implemented.

\section{Why does this study matter to clinicians?}

Other strategies may be required to increase awareness of and compliance with guidelines for transfusion in iron deficiency anemia.

\section{Introduction and background}

Iron deficiency anemia is a type of microcytic anemia that is diagnosed when the hemoglobin (hgb) is below normal and mean cell volume is below $75 \mathrm{fL}$ [1]. The primary treatment for iron deficiency anemia is oral or intravenous iron, but in an emergency setting for patients who are actively bleeding or unstable, red blood cell transfusion may be necessary. Transfusion of red blood cells should be done sparingly and in accordance with Choosing Wisely Canada recommendations based on guidelines released by the American Association of Blood Banks (AABB) [2-5]. The consensus is that transfusions should not be considered first line therapy in stable patients with hemoglobin greater than 70 [5].

The goal of the present study was to determine the number of potentially avoidable transfusions (as defined by clinical practice guidelines indicated by the Choosing Wisely Canada guidelines [2-5]) that were ordered in Calgary Zone emergency departments (EDs) from 2014 to 2019 and to determine if this number has changed significantly since the release of the guidelines in 2016.

\section{Methods}

\section{Study design and time period}

We conducted an observational cohort study in Calgary, Canada based upon administrative data obtained from Sunrise Clinical Manager and Laboratory Services databases by Alberta Health Services. We examined a 6-year period from January 1, 2014 to December 31, 2019 consisting of a 30-month baseline period and a 42-month post-intervention period.

\section{Study setting}

We examined patients presenting to four metropolitan EDs: Rockyview General Hospital, Foothills Medical Center, Peter Lougheed Center, and South Health Campus in Calgary which share an electronic health record and administrative databases.

\section{Population}

For the present study, we included men and women above 17 years of age presenting to ED with a hemoglobin less than 135 in men and less than 120 in women, and a mean cell volume less than 75 between January 2014 and December 2019.

We excluded individuals who presented with acute active bleeding or trauma.

Intervention:

We examined the effect of an intervention on potentially avoidable transfusions post-release of Choosing Wisely Canada guidelines. The intervention consisted 
of order set changes within the computerized physician order entry system which took place in July 2016. The order set changes included messaging to the ordering physician regarding hemoglobin thresholds and transfusion guidelines. In addition, physician education was delivered over an 18-month period including dissemination of guidelines, grand rounds, visiting lectures, and a local conference dedicated to transfusion appropriateness [6].

\section{Outcome measures}

Our primary outcome was the proportion of patients with iron deficiency anemia receiving a hemoglobin transfusion outside of clinical guidelines over time. A transfusion was considered outside of clinical guidelines if the patient's hemoglobin was $>70 \mathrm{~g} / \mathrm{L}$ and if the patient had a heart rate $<100$ beats per minute and systolic blood pressure $\geq 100 \mathrm{mmHg}$ ).

\section{Data analysis}

We collected the following data points electronically: blood pressure at triage, heart rate at triage, hemoglobin at presentation, mean cell volume at presentation, red blood cell units ordered (if any), time of order, and ordering physician.

We divided the 6-year time period (2014-2019) into quarters and plotted the number of potentially avoidable transfusions and total transfusions among eligible patients before and after the intervention and performed an interrupted time-series analysis to evaluate the effect of intervention. This was done by identifying baseline trend, and then examining changes in level and trend after the intervention, assuming linearity of trend lines in each segment. In addition, we assessed the secular trend of the proportion over the study period using a time series regression model.

The study was approved by the Conjoint Health Research Ethics Board at the University of Calgary, which operates according to the Tri- Council Policy Statement: Ethical Conduct for Research Involving Humans (Research Ethics Board ID: REB18-0575).

\section{Results}

We analyzed a total of 11,786 encounters and the proportion of guideline indicated transfusions during a 30-month baseline period of January 1, 2014 to June 30, 2016 and a 42-month post-intervention period of July 1, 2016 to December 31, 2019.

Our primary outcome was the proportion of patients with iron deficiency anemia receiving a hemoglobin transfusion outside of clinical guidelines over time and whether it changed after interventions were implemented.

There were 4701 encounters in the pre-intervention period and 7085 encounters in the post-intervention period. In total, 1409 (12.0\%) of the 11,786 encounters received transfusions; 1127 of the 1409 transfusions (80.0\%) were indicated while 281 (19.9\%) were potentially avoidable. In the pre-intervention period (13.1\%), there were 618 total transfusions and out of these, 133 were potentially avoidable $(21.5 \%)$. In the post-intervention period, there were $791(11.2 \%)$ total transfusions and out of these, $148(18.7 \%)$ were potentially avoidable.

The rate of potentially avoidable transfusions decreased every quarter prior to the intervention by $0.6 \%$ which was not statistically significant $(p=0.15, \mathrm{CI}=[-0.014,0.002])$ (Fig. 1).In the first quarter of the intervention, there appeared to be a $5 \%$ increase in the rate of potentially avoidable transfusion rate which was not statistically significant $(p=0.30$, $\mathrm{CI}=[-0.04,0.13])$. Thereafter, the rate of potentially avoidable decreased quarterly at a rate of $0.5 \%$ which was not statistically significant $(p=0.25, \mathrm{CI}=[-0.015,0.004])$.

Overall, the secular trend of total transfusions showed a decline of $0.1 \%$ per quarter and the decrease was statistically significant $(p$ value $=0.01,95 \%$ CI: $(-0.002,-0.0005)$ (Appendix Figure A).

There still exists significant physician variation in transfusion rates (Appendix Figure B). There was no difference in potentially avoidable transfusion or total transfusion rates between hospital sites.

\section{Discussion}

\section{Interpretation of findings}

We observed a downward secular trend in the use of blood transfusions. There was no difference in potentially avoidable transfusion rates when comparing the time period before and after the intervention was instituted. The pre-existing secular trend of decreasing transfusion ordering may have limited the effectiveness of our knowledge translation intervention. Total transfusion rate is already declining amongst ED physicians in Calgary and this may have resulted in the present null finding.

\section{Comparison to previous studies}

We determined that the rate of total transfusions in patients with iron deficiency anemia was $11.2 \%$ and the rate of potentially avoidable transfusions was $18.7 \%$, after the institution of Choosing Wisely Canada guidelines. Research 
Fig. 1 Rate of potentially avoidable transfusions in the pretreatment period (left of dashed line) and post-treatment period (right of dashed line)

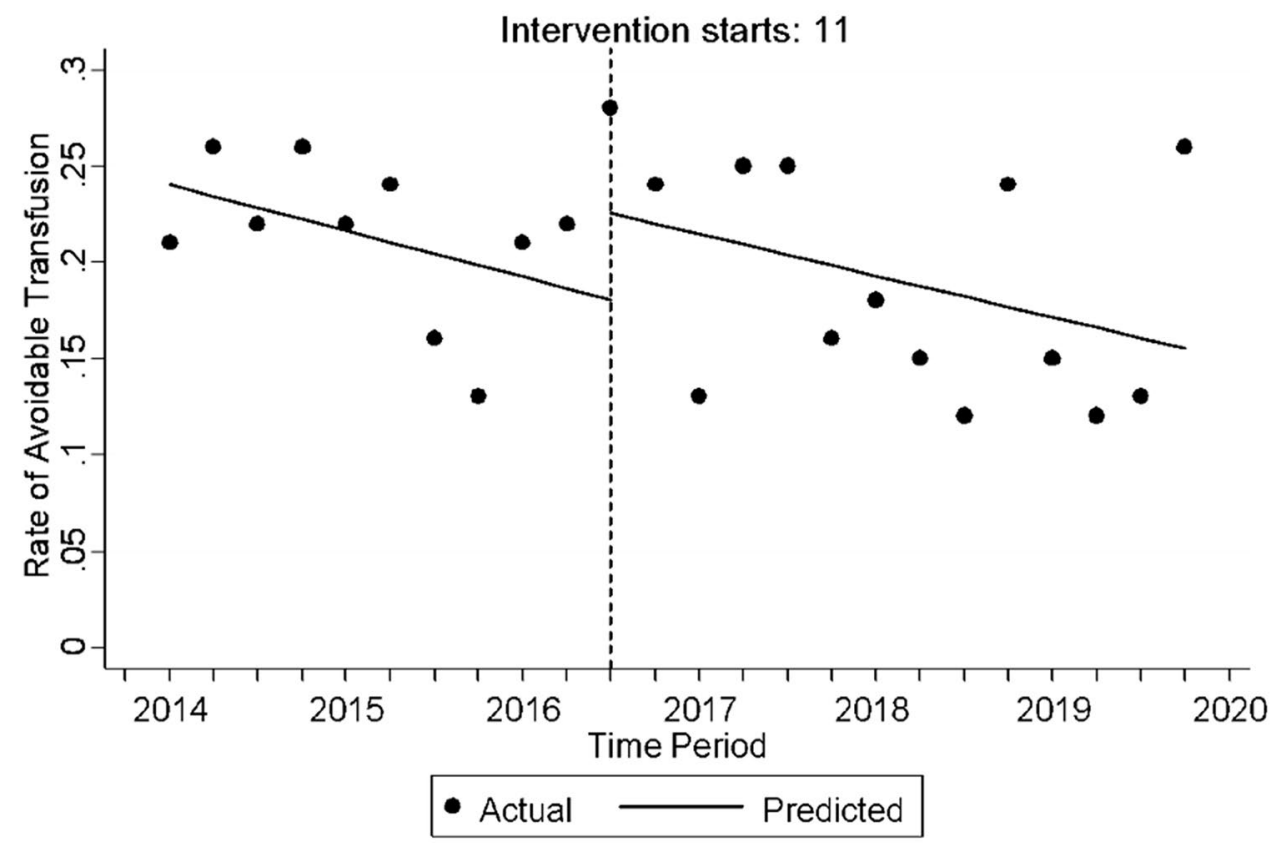

Regression with Newey-West standard errors - $\operatorname{lag}(0)$ investigating $\mathrm{RBC}$ transfusions in iron deficiency anemia patients in emergency departments is limited but ranges from 11 to $47 \%[7,8]$.

\section{Clinical implications}

Using a liberal transfusion strategy (transfusing at a hemoglobin of $90 \mathrm{~g} / \mathrm{dL}$ ) outside of Choosing Wisely Canada guidelines is not superior compared to restrictive strategies in patients with gastrointestinal (GI) bleeding [9] and may be associated with risks of iatrogenic harm [10]. Changes to computerized ordering software had no impact on transfusion utilization by emergency physicians. Further work should evaluate the effectiveness of other knowledge translation strategies.

\section{Strengths and limitations}

The primary strengths of the study are in the large sample size and broad time period over which data were collected and analyzed.

One of the limitations of our study is that we did not examine individual physician variation over time. It would be useful to know how individual physicians transfused and what individual interventions affected their transfusion rate.

\section{Conclusions}

The present study was the first to investigate the rate of red blood cell transfusions in the emergency departments of four tertiary care centers over a 6-year timespan and was the largest study to investigate red blood cell transfusions for iron deficiency anemia.

Supplementary Information The online version contains supplementary material available at https://doi.org/10.1007/s43678-021-00082-2.

\section{Compliance with ethical standards}

Conflict of interest The authors declare no conflict of interest.

\section{References}

1. World Health Organization, United Nations Children's Fund, United Nations University. Iron deficiency anaemia assessment, prevention, and control: a guide for programme managers Geneva: WHO; 2001 [cited 2018]. http://www.who.int/nutrition/publicatio ns/en/ida_assessment_prevention_control.pdf.

2. Canadian Society for Transfusion Medicine, Canada CW. Transfusion medicine-ten things physicians and patients should question Ontario: Choosing Wisely Canada; 2017

3. Franchini M, Marano G, Mengoli C, Pupella S, Vaglio S, Muñoz M, et al. Red blood cell transfusion policy: a critical literature review. Blood Transfusion. 2017;15(4):307-17. 
4. Carson JL, Guyatt G, Heddle NM, Grossman BJ, Cohn CS, Fung MK, et al. Clinical practice guidelines from the AABB: red blood cell transfusion thresholds and storage. JAMA. 2016;316(19):2025-35.

5. Practice TO. Guideline for red blood and plasma transfusion 2009. http://www.topalbertadoctors.org/download/423/blood_ trasnfusion_pda.pdf?_20180213182542.

6. Le Grand RR, Narvaez Y, Venkatesh AK, Fleischman W, Hall MK, Taylor RA, Hersey D, Sette L, Melnick ER. Improving emergency physician performance using audit and feedback: a systematic review. Am J Emerg Med. 2015;33(10):1505-14. https:// doi.org/10.1016/j.ajem.2015.07.039 (Epub 2015 Jul 23 PMID: 26296903).

7. Spradbrow J, Lin Y, Shelton D, Callum J. Iron deficiency anemia in the emergency department: over-utilization of red blood cell transfusion and infrequent use of iron supplementation. Cjem. 2017;19(3):167-74.

8. Khadadah F, Callum J, Shelton D, Lin Y. Improving quality of care for patients with iron deficiency anemia presenting to the emergency department. Transfusion. 2018;58(8):1902-8.

9. Villanueva C, Colomo A, Bosch A, Concepción M, HernandezGea V, Aracil C, et al. Transfusion strategies for acute upper gastrointestinal bleeding. N Engl J Med. 2013;368(1):11-21.

10. Callum JL, Pinkerton PH, Lima A, Lin Y, Karkouti K, Lieberman L, et al. Risk charts. In: Bloody easy 4: blood transfusions, blood alternatives and transfusion reactions - a guide to transfusion medicine. 4th ed. Ontario Regional Blood Coordinating Network; 2016. pp. 42-5. 